suggestive; the natural history of the district receives a due share of attention, and in the two reports before us we havelists of the birds, Lepidoptera, and flowering plants, with dates of appearance, record of new species, \&c., besides a copious list of local Lias fossils. A museum and library are in course of formation.

The Wellington College Natural History Society held its first meeting on May 13, 1868, and its rules are based upon those of the Rugby Society. One report only has as yet been published, in which we find selections from the papers, including one by Professor Kingsley. Botanical and ornithological lists are given, but the comparatively recent formation of the Society renders any detailed criticism unnecessary.

Last comes the Winchester College Natural History Soctety, established in March last, a notice of which has already appeared in NATURE. Of course little has been done, and nothing published at present; but we learn from the secretary that the plan of working by sections has been adopted, and that the meetings are well attended. To this and to all similar bodies we heartily wish success.

We are sorry to see that Eton is "conspicuous by its absence" from our list. The publication, two years since, of "The Birds of Berkshire and Buckinghamshire," by Mr. Clark-Kennedy, "an Eton boy," induced us to hope that a school which in position is second to none, would not be left behind in the onward march ; but as far as we can ascertain, nothing in the way of a society has been established at present. We shall be glad to learn that we are mistaken in this matter, and trust that, even should no such body at present exist, it may not be long before we hear of its formation.

\section{THE RELATIVE VALUE OF CLASSICAL AND SCIENTIFIC TRAINING}

Wodurch die humanistischen Gymnasien für die Universität vorbereiten? Rede an die Studirenden der Ludwig-Maximilian's Universität zu München gehalten am 4 Dezember, I869, von Dr. Med. Max v. Pettenkofer, Professor der Hygiène, z. z. Rector. (München, 1869.)*

$T$ HE German:reading public can possess itself at a 1 very trifling cost of a very weighty opinion as to the relative value of classical and of scientific training, by the purchase of an address delivered last December in Munich by Professor Max v. Pettenkofer, in his capacity of Rector or Chancellor of the University for the time being. There is in existence an English document (we fear we cannot speak of it as a publication) in the shape of a report, laid before the authorities of Owens College, Manchester, which has appended to it a name nearly, or quite, as familiar to the student and readers of NATURE as Pettenkofer's-viz., that of Professor Roscoe, and in which the same process of "ponderation" is applied to the classical "Gymnasia" and the modern "RealGymnasien" severally. V. Pettenkofer, who is not referred to in that report, shall here speak for himself, * "In what way do classical schools give students a preparation for the
University?" An address delivered to the students of the Ludwig-Maximilian University in Munich, on the $4^{\text {th }}$ of December, 8869 , by Mar. Pettenkofer, M.D., Professor of Hygiène, aud at the time Rector of the University. (Munich, $\mathrm{x} 869$.) and we may say at once, that after stating more or less fully the objections which are ordinarily urged against the classical system, he declares himself an adherent of the party which stands super antiquas vias. The two delegates of Owens College appear to incline in the same direction somewhat, but are more eclectic and more careful in balancing their utterances as to the possibility of combining the two systems than either v. Pettenkofer, whom we shall forthwith cite on the one, or than Helmholtz, whom they cite on the other side.

The argument from authority has a legitimate place in questions concerning such matters as the genesis of culture and as the existence of capacity and capabilitics ; for in such questions neither the facts themselves nor the mode of their origination can be always looked upon as beyond the region of probability. But as we are writing in a scientific periodical, we will begin at least with something which admits of being quantitatively estimated; and we will do this by giving the time-tables of the classical (Humanistischen) and of the modern (Real-Gymnasien) schools in Bavaria, as we find them in v. Pettenkofer's address (pp. 5 and $x 8$ ).

In classical schools, out of 99 hours per week :- 8 hours per week are given to German.

$\begin{array}{rlll}26 & \text { ", } & \text { ", } & \text { Latin. } \\ 2 \% & \text { ", } & \text { ", } & \text { Greek. } \\ 8 & \text { ", } & \text { French. }\end{array}$

(i.e., 64 hours, or 65 per cent., are given to languages, three-fourths being Latin and Greek, and one-fourth German and French.)

I7 hours per week are given to Mathematics.
I0 ", ",
8 ", History.

In "Real-Gymnasien," out of IIz hours pcr week :9 hours per week are given to German.

$\begin{array}{rlll}\text { I4 } & \text { " } & , & \text { Latin. } \\ \text { I3 } & , & ", & \text { French. } \\ 4 & \text { " } & \text { ", } & \text { English. }\end{array}$

(i.e., 40 hours, or 33 per cent, are given to languages, of which time only one-third is given to one ancient language, onethird to French, the other two-thirds to German)

27 hours per week are given to Mathematics.

(i.e., algebra, elementary geometry, trigonometry, descriptive and analytical geometry and higher ana ysis, taking 22 per cent. of the whole number)
4 hours per week are given to History.
I9
, " ,
Natural Science and Geo- graphy.
$\begin{array}{rlll}24 & " & , & \text { Drawing and Modelling } \\ 8 & \text { " } & , & \text { Religious Instruction. }\end{array}$

The "Real-Gymnasien" are thus seen to exact $25 \mathrm{pcr}$ cent. more hours than the classical schools; and it is by this increase on the one hand, coupled with a curtailment of the quota assigned to languages on the other, that time is found for mathematics and for natural science, with the drawing and modelling so indispensable to it. V. Pettenkofer deprecates the making of any material increase in the number of hours to be spent in the gymnasien, on the undeniable ground that the day is no longer, and man no stronger now than were the days and the men of 2,000 years ago ; and space for such additamenta as must be made to the curriculam must be found by 
bettering the methods and means for communicating instruction, and effecting thus an economy of time.*

The Bavarian chemist and hygienist does not himself suggest any ways and means whereby this economy may be effected, and presumptuous though it be, we will attempt to supplement this deficiency by saying that such an economy might be effected in England and English schools by applying one or other or all three of the following lines of treatment to the classical curriculum, ever without cutting its Greek adrift. Latin and Greek, to put the boldest suggestion first, might be studied in certain, and those not a few, cases, as literatures and not as philologies; or, as a second alternative, when some training in philology is to be retained at whatever cost, such training might be made more intelligible and so less distasteful and wasteful of time, by making the study of it comparative, as recommended by Professor Max Müller in his evidence before the Commission just referred to ; or thirdly, synthetical scholarship, in the way of verse-making, should be considered as a luxury and refinement to be reserved for the delectation and cultivation of those few who, in any age, show any aptitude for it, and synthetical scholarship in the way even of writing Latin prose might, due precautions having been taken, be dispensed with in the cases of youths who, whilst wholly incapable in that, had shown some capacity in some other line. Our "due precautions" should consist in the multiplying the practice of synthetical scholarship in the way of translation from Latin into English. We know the horror which these suggestions will excite in the breasts of schoolmasters of the type represented by the gentleman who told the Commissioners already referred to, that if he were set to teach History in set lessons, he "should not know how to do it." But we believe that by the adoption of any one of the three lines of action, just glanced at, space and time might be found for the introduction of the natural sciences into the curriculum of any public school, and that at once without injury to the dignity of either the one or the other of the two sets of studies, and without injury to the physical or mental health of the learners.

But it is time, perhaps, that we should let v. Pettenkofer spcak for himself; and this he does (at p. I2, l.c.) to the following effect:- "I am convinced that philology and mathematics furrish precisely the material for teaching and intellectual discipline which is essential for our gymnasia, and I look upon the material furnished by other sciences as mere accessories. I know that in putting forward this view, which I do not do now for the first time, I put myself into opposition with the tide of opinion which is prevalent just at present, and which anticipates great advantages from the introduction of additional

* It may be well here to lay an English programme or schoul-work alongside of the two above : given schedules of German school-work. A scheme to the following effect may be found as suggested by the Public School Commissioners, in their report, vol. i., $x \& 64$, pp. 34,35 :-

\section{In an English public school of 39 hours per week-}

II hours are to be ass:gned to Classics, History, and Divinity (lessons)

$\begin{array}{llll}\text { ro } & " & \text { " } & \text { Arithmetic and Mathematics, i.e., not less. } \\ 3 & " & " & \text { French and German (lessons). }\end{array}$

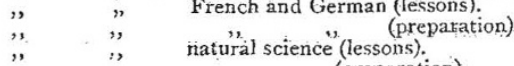

music and drawing.

composition. subjects of instruction, and especially from the introduction of instruction in natural science into 'Latin schools (Lateinschulen) and gymnasia." Further on (p. i6) he proceeds as follows:- "The results of actual experience appear to me to favour my views. In other parts of Germany, experiments have now, for a long while, been made with gymnasia and similar institutions, in which much natural science is taught. But I cannot as yet discover that any remarkable number of persons who have subsequently distinguished themselves in natural science have come from these schools. In this matter reliable statistics of the pupils leaving (der Abiturienten) a Berlin gymnasium, the so-called 'Old Cologne Gymnasium,' in which natural science has for a long while formed part of the curriculum, would be very instructive. Distinguished men come, from time to time, from this gymnasium, but certainly not in greater numbers than from any other classical (Humanistischen) gymnasium where no natural science at all is taught. It would long ago have beer a notorious fact if a disproportionate number of the younger professors of natural science in the Prussian Universities could have been shown to have been formerly students in the Cologne Gymnasium."

We imagine that this "Old Cologne Gymnasium," thus referred to by v. Pettenkofer, is none other than the "mixed" (simultan) school described by Mr. Matthew Arnold under the name of the Friedrich Wilhelm's Gymnasium at Cologne, in his "Schools and Universities of the Continent," pp. 218-221 ; and but that more antagonism and less familiarity subsisted between North and South Germany six months ago than, we are happy to think, subsists now, we apprehend that more would have been made of the history of this institution by the Munich Professor. For Dr. Jaeger, the director of this mixed school, who, as he had been refused a nomination to another school, the Bielefeld Gymnasium, by the Education Minister, on account of his politics, cannot be suspected of reactionary leanings, spoke to Mr. Arnold in the following sense (see p. 22I, l.c.): "It was the universal conviction with those competent to form an opinion, that the Realschulen were not at present successful institutions. He declared that the boys in the corresponding forms of the classical school beat the Realschule boys in matters which both do alike, such as history, geography, the mother tongue, and even French, though to French the Realschule boys devote far more time than their comrades of the classical school. The reason for this, Dr. Jaeger affirms, is that the classical training strengthens a boy's mind so much more. This is what, as I have already said, the chief school authorities everywhere in France and Germany testify. In Switzerland you do no hear the same story."

With regard to Switzerland, we learn from the Owens College Report above mentioned that Professor Zeuner of the Polytechnic School at Zurich, holds that the establishment of "Real Gymnasia," or High Schools of Science, to take equal rank with the old classical gymnasia, and to put pure and applied science on the same footing for educational purposes as that which the classics enjoy in these schools, is a desirable thing, but that he allows that by the introduction of a "bifurcation" system into the older schools they might be made equal to meeting all modern requircments. Heimhoitz, on the other hand, may in the 
same report be found pleading strongly for "the foundation on equal terms of complete academic institutions for science" as a "counteraction of the tendency of classical men to lean on authority alone."

"Philological culture," says the eminent physiologist of Heidelberg, "has an ill effect on those who are to devote themselves to science; the philologist is too much dependent on authority and books, he cannot observe for himself, or rely upon his own conclusions, and having only been accustomed to consider the laws of grammar, all of which have their exceptions, he cannot understand the invariable character of physical laws." Granting with all respect the premises laid down by Professor Helmholtz, we should demur to the conclusion which he would base upon them, and profess ourselves unable to see that, because particular institutions had a tendency to dwarf and stunt particular faculties, they should therefore be left undisturbed to do this evil work uncounteracted. And still leaving the premises unimpugned, we should set up a cross-indictment to the effect that if classical studies left the student of them unacquainted with the invariability of natural laws, physical studies leave the student unacquainted with the variability of men's minds. But, so far as the business of life consists in having to do business and hold intercourse with our fellow-men, this acquaintance with the variability of men's minds is simply the particular kind of knowledge which is not only the most practically useful and marketable of all kinds of knowledge, but is precisely the kind which, by common consent, is allowed to characterise if not to constitute "culture."

Lord Lyttelton, however, and the Endowed Schools Commissioners would appear to be in favour of the establishment of locally distinct schools for the two sets of studies and of students, and herein to be at one with Helmholtz. The Owens College Delegates, on the other hand, are, like ourselves, in favour of a system of bifurcation, which would not necessarily keep apart persons of different mental conformation who might be much benefited by mutual contact. They have come to this conclusion mainly for reasons based on observations and testimony given in Germany. Our peculiar social organisation makes the question more complex for us; but we, too, have our experience as well as the Germans; and time has shown that an Englishman, whose reputation as an educationalist is equal to that of Helmholtz as a physicist, may, in this very matter, be as far wrong as we believe that great physicist to be. In 1864 Dr. Temple told the Public Commissioners (see Report, vol. ii., p. 312) that he should "not consider it wise to follow the Cheltenham and Marlborough examples by attaching to the public schools modern departments. The classical work would lose, the other work would not gain!" In 1867 we find a distinguished Rugby master, the Rev. J. M. Wilson, speaking to the following effect of the results produced by the changes set on foot in accordance with the proposals of the Public Schools Commissioners, and earnestly and honestly carried out. "Lastly, what are the general results of the introduction of scientific teaching in the opinion of the body of the masters? In brief it is this : that the school, as a whole, is better for it, and that the scholarship is not worse. . . . This is the testimony of classical masters, by no means specially favourable to science, who are in a position which enables them to judge. . . . It is believed that no master in Rugby School would wish to give up natural science and recur to the old curriculum."

G. ROLLESTON

\section{PAMPHLETS ON METEOROLOGY AND \\ MAGNETISM}

Fournal of the Scottish Meteorological Society. (Blackwood and Sons.)

The Normal Winds of Bombay. By C. Chambers, F.R.S

WE have received the Fournals of the Scottish Meteorological Society from the beginning of 1867 to the end of last year, and we find them, on inspection, to be full of a variety of interesting and valuable matter.

The Scottish Society does not confine its attention to one particular branch of meteorology, but is broad in its sympathies as well as energetic in the development of its objects, and it is no doubt owing to this that so much is done with comparatively small means, and so much ground occupied with advantage. Among the numerous papers which constitute these journals we observe an address by that veteran agriculturist, the Marquis of Tweeddale, "On the effects of solar radiation in relation to crops." Anything on this subject is interesting from one who has himself grown wheat on the fields of India, and baked it into loaves which were duly distributed to his various sceptical friends.

We note with pleasure a proposal by the noble author for two experiments on the physiological branch of meteorology, firstly, What portion of the value of the sun's direct rays is due to heat, and what to light? and secondly, Whether the heat is of value as applied to the roots in the soil, or as regards its stimulating effects on the plant above ground?

The indefatigable secretary of the society, Mr. Alex. Buchan, contributes many interesting papers, and among them a series on the well-known interruptions in the regular rise and fall of temperature in the course of the year. Six cold and three warm periods are discussed and the author arrives at the following conclusion :-

"The unusually cold or warm periods which occus with considerable regularity at certain times of the year have, so far as we have examined them, been proved to depend on the relations of the polar and equatorial currents to each other. And the circumstance that one of these great atmospheric currents and not the other prevails over this portion of the earth's surface at stated seasons, is a valuable fact in meteorology, particularly in the light it seems to cast on the periodicity of weather changes."

In another memoir, Mr. Buchan discusses the cold weather of March 1867 , which he attributes to the unprecedentedly high atmospheric pressure which prevailed in the north and north-west of Europe from the beginning to the 24 th of the month.

Mr. Thomas Stevenson, in another very valuable and original paper, introduces the method of Barometric gradients as a means of ascertaining the intensity of storms. Very probably it may ultimately be found that we can measure a storm better by the Barometric differences which cause it than by the violence of the wind which constitutes it a storm, but the first step is surely to measure directly and accurately the intensity of storms considered as independent phenomena, and the second 